\title{
Approaching Freshet beneath Landfast Ice in Kugmallit Bay on the Canadian Arctic Shelf: Evidence from Sensor and Ground Truth Data
}

\author{
TONY R. WALKER, ${ }^{1,2}$ JON GRANT $^{1}$ and PETER JARVIS ${ }^{1}$
}

(Received 5 February 2007; accepted in revised form 18 July 2007)

\begin{abstract}
The Mackenzie River is the largest river in the North American Arctic. Its huge freshwater and sediment load impacts the Canadian Beaufort Shelf, transporting large quantities of sediment and associated organic carbon into the Arctic Ocean. The majority of this sediment transport occurs during the freshet peak flow season (May to June). Mackenzie River-Arctic Ocean coupling has been widely studied during open water seasons, but has rarely been investigated in shallow water under landfast ice in Kugmallit Bay with field-based surveys, except for those using remote sensing. We observed and measured sedimentation rates $\left(51 \mathrm{~g} \mathrm{~m}^{-2} \mathrm{~d}^{-1}\right)$ and the concentrations of chlorophyll $a$ (mean $2.2 \mu \mathrm{g} \mathrm{L}^{-1}$ ) and suspended particulate matter $\left(8.5 \mathrm{mg} \mathrm{L}^{-1}\right)$ and determined the sediment characteristics during early spring, before the breakup of landfast ice in Kugmallit Bay. We then compared these results with comparable data collected from the same site the previous summer. Comparison of organic quality in seston and trapped material demonstrated substantial seasonal differences. The subtle changes in biological and oceanographic variables beneath landfast ice that we measured using sensors and field sampling techniques suggest the onset of a spring melt occurring hundreds of kilometres farther south in the Mackenzie Basin.
\end{abstract}

Key words: Mackenzie River, Kugmallit Bay, spring melt, sediment transport, landfast ice

RÉSUMÉ. Le fleuve Mackenzie est le plus grand fleuve de l'Arctique nord-américain. Son énorme bassin d'eau douce et sa masse de sédiments ont des effets sur la plateforme externe de la mer de Beaufort canadienne, transportant ainsi de grandes quantités de sédiments et de carbone organique associé dans l'océan Arctique. La plus grande partie du transport des sédiments se produit pendant la saison haute d'écoulement du courant d'eau douce dans la mer (de mai à juin). Même si le couplage du fleuve Mackenzie et de l'océan Arctique a fait l'objet d'études approfondies durant les saisons d'eau libre, il a rarement été étudié en eau peu profonde sous la banquise de la baie Kugmallit au moyen d'études sur le terrain, sauf dans le cas d'études faisant appel à la télédétection. Nous avons observé et mesuré les taux de sédimentation $\left(51 \mathrm{~g} \mathrm{~m}^{-2} \mathrm{~d}^{-1}\right)$ et les concentrations de chlorophylle $a$ (moyenne de $\left.2,2 \mu \mathrm{g} \mathrm{L}^{-1}\right)$ et de matière particulaire en suspension $\left(8,5 \mathrm{mg} \mathrm{L}^{-1}\right)$, puis déterminé les caractéristiques des sédiments au début du printemps, avant la rupture de la banquise dans la baie Kugmallit. Ensuite, nous avons comparé ces résultats à des données comparables recueillies au même emplacement l'été précédent. La comparaison de la qualité organique du seston et des matières emprisonnées faisait ressortir d'importantes différences saisonnières. Les changements subtils sur le plan des variables biologiques et océanographiques sous la banquise que nous avons mesurés à l'aide de capteurs et de techniques d'échantillonnage sur le terrain laissent entrevoir un début de fonte du printemps se produisant à des centaines de kilomètres plus au sud, dans le bassin du Mackenzie.

Mots clés : fleuve Mackenzie, baie Kugmallit, fonte du printemps, transport des sédiments, banquise

Traduit pour la revue Arctic par Nicole Giguère.

\section{INTRODUCTION}

The Mackenzie River is the only North American analog of the large Siberian rivers that flow into the Arctic. Although the Siberian rivers have a greater water discharge (Burenkov et al., 1997; Kuptsov et al., 1999; Wegner et al., 2003), the Mackenzie River has a higher sediment loading per volume (O'Brien et al., 2006). Its drainage basin covers an area of $1.8 \times 10^{6} \mathrm{~km}^{2}$. It flows from the Rocky Mountains northwards into the Beaufort Sea and the Arctic Ocean (Hill et al., 2001). Each year, it discharges large amounts of fresh water $\left(330 \mathrm{~km}^{3}\right)$, sediments
$(127 \mathrm{Mt})$, and vast quantities of terrestrial organic carbon (2 Mt) (Yunker et al., 1995; Macdonald et al., 1998), making it the largest source of sediment to the Beaufort Shelf (O'Brien et al., 2006).

The Mackenzie Shelf is dominated by seasonal ice from October until May/August, with continuous input of fresh water from the Mackenzie throughout the year. The nearshore zone of Kugmallit Bay has water depths that may be less than the thickness of the landfast ice and can be frozen to the seabed as "bottomfast" ice (Hill et al., 2001). Beyond the landfast ice are the mobile polar pack and transition zone (the Stamukhi zone). The Stamukhi is

\footnotetext{
${ }^{1}$ Department of Oceanography, Dalhousie University, Halifax, Nova Scotia B3H 4J1, Canada

${ }^{2}$ Present address: Dillon Consulting, 137 Chain Lake Drive, Halifax, Nova Scotia B3S 1B3, Canada; twalker@dillon.ca

(C) The Arctic Institute of North America
} 
formed by the convergence of stationary landfast ice and drifting ice (Carmack et al., 2004). During late winter, the estuary and the nearshore remain covered with landfast and bottomfast ice, forcing the water to either find deeper channels under the ice or overflood the surface (Macdonald et al., 1999). As spring progresses, breakup begins and the landfast ice disappears.

The spring flood and associated river ice breakup represents the most important event of the year, playing a large role in sediment transport and shaping adjacent physical, biological, and human interactions. For example, the beluga whales, which are an important source of food for the Inuvialuit, return in late June or early July (Usher, 2002). Most of the total annual discharge takes place while ice jams and landfast ice in the Mackenzie Delta are melting, during late May and early June. Consequently, this is also the peak sediment discharge period. Both water discharge and sediment discharge decrease steadily during the summer (Hill et al., 2001).

At this time the nearshore zone is dominated by the river plume, creating strong gradients of turbidity, salinity, and temperature (Macdonald et al., 1995, 1998; Lintern et al., 2005; J. Haaf et al., unpubl. data; H. Jakes et al., unpubl. data). During the winter ice-covered period, a "winter plume" still manages to discharge substantial quantities of sediment and freshwater (Carmack and Macdonald, 2002; Carmack et al., 2004); however, it is modest when compared to summer discharge levels.

The western Canadian Arctic, specifically the southern Beaufort Sea encompassing the Mackenzie Shelf, the Cape Bathurst Polynya, and Amundsen Gulf, has experienced alarming increases in surface temperature over the last few decades (IPCC, 2001; Comiso, 2003), as well as a reduction in sea-ice thickness since the early 1980s (Barber and Hanesiak, 2004). The reduced ice thickness, along with early snowmelt in the drainage basin, will produce earlier open-water conditions on the shelf (Macdonald et al., 1995). These climatological factors contribute to increased fluxes to the outer shelf of sediments resulting from erosion and re-suspension, greater export of suspended particulate matter (SPM), and a net decrease in primary production due to its suppression by the high turbidity of the Mackenzie plume in spring and early summer (Hill and Nadeau, 1989; Carmack et al., 2004).

Land-derived organic carbon accounts for the majority of the organic matter in Beaufort Shelf sediments (Yunker et al., 1995, 2005; Goñi et al., 2000). Although coastal erosion provides an additional source of terrestrial organic carbon to the Mackenzie Shelf, its contribution is minimal ( 7\%; Macdonald et al., 1998). Concentrations of SPM in the surface layers of the Mackenzie Shelf and Beaufort Sea show significant seasonal variations, with winter SPM concentrations as low as 3 to $12 \mathrm{mg} \mathrm{L}^{-1}$ and peak summer SPM concentrations reaching up to $4000 \mathrm{mg} \mathrm{L}^{-1}$ (Hill et al., 1991; Macdonald et al., 1998). The Mackenzie River therefore produces important consequences for the total carbon budget in the Arctic through the flow of terrestrial organic carbon through food webs, horizontal transport of SPM, the coupling of primary production with benthic production, and the delivery of organic matter to benthic communities (Macdonald et al., 2003; Carmack et al., 2004).

During the brief open-water conditions in Kugmallit Bay, gales cause wave energy to increase. Coupled with strong storm surges, this increased wave energy results in major re-suspension of bottom sediments, contributing to the horizontal transport of sediments and organic carbon to the Beaufort Shelf (Harper et al., 1988; Hill and Nadeau, 1989; Lintern et al., 2005; Walker et al., 2005, in press). Such rapid transport and alteration of sediments favors opportunistic infaunal species that can either avoid such events or re-colonize quickly after them. For example, Conlan and Kvitek (2005) found that the dorvilleid polychaete Ophryotrocha spatula was the first to re-colonize soft sediments after ice scours in Barrow Strait. Other benthic organisms that were capable of inhabiting these dynamic environments were juvenile bivalves Serripes groenlandicus, the oedicerotid amphipod Monoculodes spp., and the hesionid polychaete Nereimyra punctata. During open water, wind-driven currents transport sediments reworked during storm events across the outer shelf in both surface plumes and near-bottom suspensions (O'Brien et al., 2006). Obtaining measurements of SPM concentrations on the Mackenzie Shelf beneath landfast ice is critical for understanding the interactions between physical and biogenic carbon cycling across the shelf and its variation with river discharge, ice cover and storms (Macdonald, 2000).

To date, most of the field studies related to fluxes of organic and inorganic particles in the Mackenzie Delta have been limited to summer observations (e.g., Hill and Nadeau, 1989; Macdonald and Thomas, 1991). Several remote sensing studies have also been used to determine the timing and spatial dynamics of river-ice breakup, showing that the spring freshet and breakup of river ice begin in the headwaters of the Mackenzie River in late April and move progressively northward downriver to the Delta (Dean et al., 1994; Pavelsky and Smith, 2004). Few field studies have been conducted during spring, as the dynamic state of ice and water make sampling hazardous, and limited data exist on the oceanographic features of the inner Kugmallit Bay (Carmack and Macdonald, 2002). Most recent studies have concentrated on sediment transport on the slope of the Mackenzie Shelf (e.g., Forest et al., 2006; O’Brien et al., 2006).

This study was undertaken during a two-stage investigation to assess nearshore-based sediment transport in the Beaufort Sea as part of the Canadian Arctic Shelf Exchange Study (CASES) project. We used sensors and ground-truthing calibration samples to monitor estuarine water temperature, salinity, current velocity, chlorophyll $a$, and SPM concentrations in order to provide early signals of the onset of breakup of landfast ice in Kugmallit Bay. In addition, we used benthic sediment samples and 
sediment traps to provide estimates of the horizontal transport and composition of sediments across a cross-section of Kugmallit Bay. We report data collected during spring (May 2005), but compare these findings with data collected from the same site the previous summer (July 2004). Results of the nearshore summer study are published elsewhere (see Walker et al., in press).

\section{MATERIAL AND METHODS}

\section{Study Sites}

As part of the Canadian Arctic Shelf Exchange Study (CASES) project (Fig. 1), sampling was conducted in inner Kugmallit Bay, south of Hendrickson Island in the east channel of the Mackenzie River, $20 \mathrm{~km}$ southwest of the hamlet of Tuktoyaktuk, Northwest Territories (NWT) during May 2005. The same site had been sampled the previous summer (July 2004), and comparisons are made between the water column and sediment variables measured. The channel in Kugmallit Bay accounts for $11 \%$ of the total river discharge of the Mackenzie River (Carson et al., 1999), and the site was chosen in the centre of this channel, which measured $17 \mathrm{~km}$ across with a mean depth of $2.5 \mathrm{~m}$.

The ice thickness on the Mackenzie Delta allows for the construction of an annual ice road connecting Tuktoyaktuk with Inuvik (a distance of $150 \mathrm{~km}$ ), which can be used from December to April. Deploying instruments within this zone is difficult, and other studies have concentrated their efforts either in the deeper waters of the shelf (e.g., Carmack et al., 2004) or during the brief open water season (Lintern et al., 2005; Walker et al., 2005, in press).

An ice hole large enough for deployment of instruments was made by drilling several holes together using an ice drill. Distance from the surface of the sea ice to the sea bed was $3.5 \mathrm{~m}$ : with an ice thickness of $1.3 \mathrm{~m}$, this resulted in just $2.2 \mathrm{~m}$ of water column. The tidal amplitude in Kugmallit Bay is small $(0.3 \mathrm{~m})$, so we took care that the change in water depth would not cause the ice cover to affect the instruments.

\section{Water Column Sampling}

A Two-Dimensional Acoustic Current Meter (2-DACM) system equipped with conductivity, temperature and depth sensor (CTD) (Falmouth Scientific Inc., FSI) and integrated Turner designs fluorometer (SCUFA ${ }^{\circledR}$, model 10 series) was deployed as a mooring at the site, approximately $1 \mathrm{~m}$ above the seabed, for five days. A schematic of mooring and sampling positions is illustrated in Figure 2. Duplicate sediment traps were also deployed at the site approximately $20 \mathrm{~m}$ away from the mooring. The 2-DACM current meter and fluorometer were secured to the bottom with a chain attached to an anchor weight. To maintain their position in the water column, the instru-
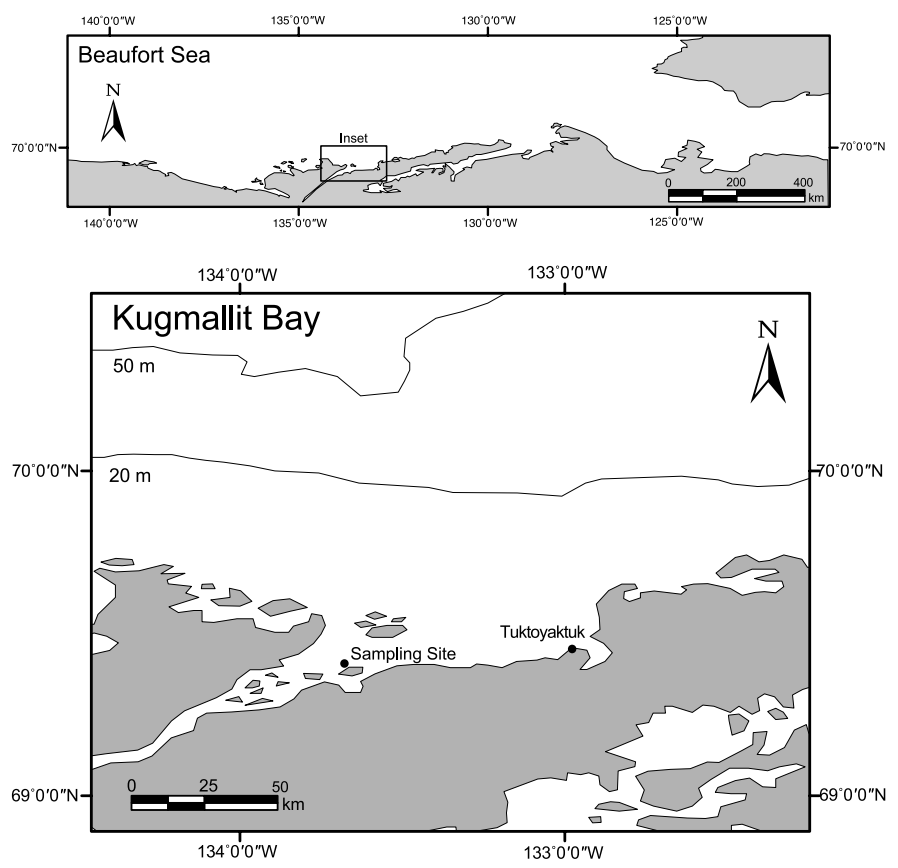

FIG. 1. Sampling site in Kugmallit Bay on the eastern channel of the Mackenzie Delta.

ments were tied with rope to a stake lying across the hole, which was then covered by blocks of snow to prevent the hole from refreezing. Parameters measured were current velocity, current direction, temperature (accuracy $\pm 0.00001^{\circ} \mathrm{C}$ ), salinity, turbidity (calibrated against fieldtruthed SPM concentrations) and chlorophyll $a$. The sampling rate of the combined current meter and fluorometer was set to collect binned data averaged every 15 minutes.

Pre-calibration of the Turner designs fluorometer was carried out with a chlorophyll $a$ primary standard (Sigma C-6144) in the lab using the methodology of Arar and Collins (1997). Additional field calibration was carried out using water samples collected at the mooring site in a 2 L Niskin bottle and then stored in pre-rinsed 1 L Nalgene

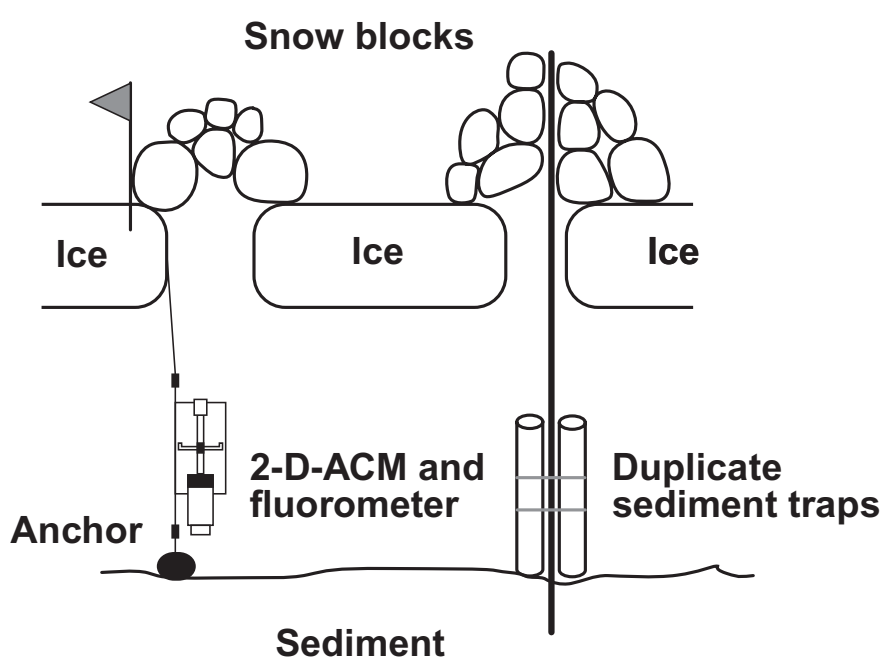

FIG. 2. Schematic diagram showing mooring and sampling positions under the ice. 
bottles. Water samples $(100 \mathrm{~mL})$ were filtered through pre-washed GF/F filters (Whatman, $47 \mathrm{~mm}$ ) and were kept frozen $\left(-20^{\circ} \mathrm{C}\right)$ until analysis. Chlorophyll $a$ concentration was measured by spectrophotometry (Turner Design's Model 10-AU-005 Field Fluorometer) using 90\% buffered acetone extraction and standard methods developed by the American Public Health Association (1998).

For analysis of SPM and water column organic matter $(\mathrm{OM})$, triplicate seawater samples were collected at intervals from the mooring site between 5 and 9 May, using a $2 \mathrm{~L}$ Niskin bottle deployed at a depth of $1 \mathrm{~m}$. The samples were then stored in pre-rinsed $1 \mathrm{~L}$ Nalgene bottles until analysis in the laboratory. Water samples of $1 \mathrm{~L}$ volume were filtered through pre-weighed GF/F filters (Whatman, $47 \mathrm{~mm}$ ), which were oven-dried overnight at $60^{\circ} \mathrm{C}$ and then re-weighed to determine SPM concentration. These $\mathrm{GF} / \mathrm{F}$ filters were retained in a furnace oven at $520^{\circ} \mathrm{C}$ for $24 \mathrm{~h}$ before being re-weighed for loss-on-ignition (LOI) analysis of water column OM.

Confirmatory measurements of salinity and temperature were also taken, using a hand-held salinity and temperature probe (YSI instruments, model YSI 30). Salinity was measured in practical salinity units (PSU).

\section{Sediment Sampling}

Benthic sediment samples were collected by hand using a $4 \mathrm{~m}$ steel sampling rod with three mini-syringe cores attached by means of cable ties. Triplicate mini-cores were taken with truncated $5 \mathrm{~mL}$ plastic syringes $(1 \mathrm{~cm}$ wide), collected over the $0-1 \mathrm{~cm}$ depth horizon and stored at $-20^{\circ} \mathrm{C}$ in pre-weighed plastic scintillation vials until analysis for density, porosity, grain size, OM, total organic carbon (TOC), and $\mathrm{C} / \mathrm{N}$ ratios. Sediment grain size was analyzed using modified protocols (see Grant et al., 2002). For each site, a thawed sample was gently shaken and then wet-sieved with tap water through a series of 63 to $2000 \mu \mathrm{m}$ sieves, with the less than $63 \mu \mathrm{m}$ effluent collected and filtered. As is typical of biogenically influenced sediments, qualitative aspects of sediment texture must be considered in the analysis. Analysis of sediment grain size distribution was carried out using a grain size distribution and statistics package for the analysis of unconsolidated sediments (GRADISTAT) developed by Blott and Pye (2001). Porosity was measured as weight loss of water upon drying at $60^{\circ} \mathrm{C}$ using $1 \mathrm{~cm}^{3}$ syringe volumes. Surface samples $(0-1 \mathrm{~cm})$ of sediment and SPM filters for LOI analysis were oven-dried at $60^{\circ} \mathrm{C}$ for $3 \mathrm{~d}$ to constant weight and then ignited in a furnace oven at $520^{\circ} \mathrm{C}$ for $24 \mathrm{~h}$ before being reweighed. Sediments for carbon and nitrogen analysis were stored in plastic vials and kept frozen at $-20^{\circ} \mathrm{C}$ before being measured in a $\mathrm{CHN}$ elemental analyzer (Perkin-Elmer 2400) with no pre-treatment.

Horizontal sediment transport and organic quality were derived from measurements of sediment accumulating in sediment traps. These traps collect only that portion of particles that settles out as the water passes over the mouth of the trap; therefore, the estimates derived from these samples are likely to underestimate the actual level of suspended sediment. The sediment traps in this environment are sampling a variety of sediment processes, which can be partially elucidated using material compositions (C, N, Chl $a$ ).

Duplicate sediment traps consisting of Perspex ${ }^{\mathrm{TM}}$ columns were deployed for four days. Traps were $90 \mathrm{~cm}$ long with $7 \mathrm{~cm}$ internal diameter (aspect ratio 13:1) and were attached to a $4 \mathrm{~m}$ steel rod and anchored into the sediment and secured at the top by covering the hole with snow blocks (Fig. 2). The aspect ratio of the sediment traps was above the 5:1 ratio suggested by Bloesch (1994) to avoid losses due to sediment re-suspension. The traps were deployed directly onto the seabed, with the collection tops $1 \mathrm{~m}$ above the sediment bed. Care was taken not to disturb or re-suspend sediment during deployment. The Perspex ${ }^{\mathrm{TM}}$ columns were sealed with plastic caps that were removed by ropes 30 minutes after deployment. As the traps were deployed for only four days, no sediment preservation technique was used, and it was assumed that sediment fluxes were not underestimated because of losses from microbial degradation (Walker, 2005).

\section{Determining Material Fluxes}

The basic oceanographic parameters measured at the site were employed to help us understand the physical processes of material fluxes in the estuary. We used equations (1) and (2) adapted from Hume and Bell (1993), in an attempt to estimate current flow and material flux of TOC through a cross-section of Kugmallit Bay that passes through the sampling site:

$$
Q_{t}=A U v
$$

where $Q_{t}=$ discharge at a specific time $\left(\mathrm{m}^{3} \mathrm{~d}^{-1}\right), A=$ area of cross-section $\left(\mathrm{m}^{2}\right), U v=$ mean velocity perpendicular to the cross-section $\left(\mathrm{m} \mathrm{s}^{-1}\right)$. The distance across the bay at the site was $17 \mathrm{~km}$, and the mean depth of the water column under ice cover was estimated at $1.5 \mathrm{~m}$.

$$
F=C Q_{t}
$$

where $F=$ total TOC flux through the cross-section $\left(\mathrm{g} \mathrm{d}^{-1}\right)$, $C=$ concentration of TOC from SPM measurements $\left(\mathrm{g} \mathrm{m}^{-3}\right)$.

\section{Statistical Analysis}

NCSS 2000 statistical software was used to perform standard statistical analyses (one-way analysis of variance, ANOVA and linear regression). Linear regression was used for the analysis of 2-D-ACM and integrated fluorometer mooring data, and one-way ANOVA was used to assess differences in water column and sediment variables. 


\section{RESULTS}

\section{Water Column}

Regression analysis of data from the 2-D-ACM and integrated fluorometer mooring over time showed there was no observed increase in temperature $\left(\mathrm{r}^{2}=0.005\right.$, $p=0.002, \mathrm{n}=489)$ or salinity $\left(\mathrm{r}^{2}=0.00016, p=0.572\right.$, $\mathrm{n}=1950$ ), but there was an obvious (albeit small) diurnal pattern in temperature (Fig. 3a). These results were confirmed by measurements taken with a hand-held temperature and salinity probe. Regular inspection of the sampling ice-hole revealed evidence of some melting of the ice. There was an increase in the current velocity over the mooring period: from 13 to $20 \mathrm{~cm} \mathrm{~s}^{-1}$ between 5 and 9 May $\left(\mathrm{r}^{2}=0.754, p<0.001, \mathrm{n}=1955\right)$ (Fig. 3b). There also appeared to be current velocity fluctuations that occurred over semi-diurnal tidal periods. Overall concentrations of chlorophyll $a$ (2 to $3 \mu \mathrm{g} \mathrm{L}^{-1}$ ) and turbidity (SPM equivalents; 6 to $15 \mathrm{mg} \mathrm{L}^{-1}$ ) were low during this study (Fig. 3c and d). The increase in chlorophyll $a$ concentration was highly correlated with time $\left(\mathrm{r}^{2}=0.806, p<0.001, \mathrm{n}=489\right)$, although the mean value of $2.2 \mu \mathrm{g} \mathrm{L}^{-1}$ was relatively low compared to typical summer values. The observed slope in chlorophyll $a$ concentration began by rising steadily but developed a steeper curve before the mooring was retrieved on 9 May. Measurements of turbidity did not show any overall increasing trend with time $\left(\mathrm{r}^{2}=0.148\right.$, $p<0.001, \mathrm{n}=1955)$ and mean values were $8.5 \mathrm{mg} \mathrm{L}^{-1}$. However, there are two trends observed in turbidity (SPM) concentration, with an initial increase between 5 May and 7 May when the maximum turbidity concentrations were recorded, this was followed by a steady decline (Fig. 3d).

Typical current speeds and directions for May and July are shown in Figure 4 and Table 1. The longer line indicates the mean flow direction, and for May (spring) the current speeds are consistently lower and fairly unidirectional flowing north-northeast. However, during July (summer) the current speeds are higher and direction is more variable, creating a more turbulent and disturbed flow compared to winter under river ice conditions.

In Table 1 we compare spring (under ice) and summer parameters for both water column and sediment variables. We observed significant differences between spring and summer at the same site in temperature, chlorophyll $a$, SPM concentration, OM content within SPM filters, and sedimentation rate $(p<0.001$ in all cases, one-way ANOVA). However, there were no differences between seasons in salinity.

\section{Sediments}

Results from OM contents collected on SPM filters and sediment characteristics (Table 1) showed significant differences between spring and summer in OM and TOC content of surface sediments $(p<0.001$ in both cases, oneway ANOVA). Differences in sediment $\mathrm{C} / \mathrm{N}$ ratios were

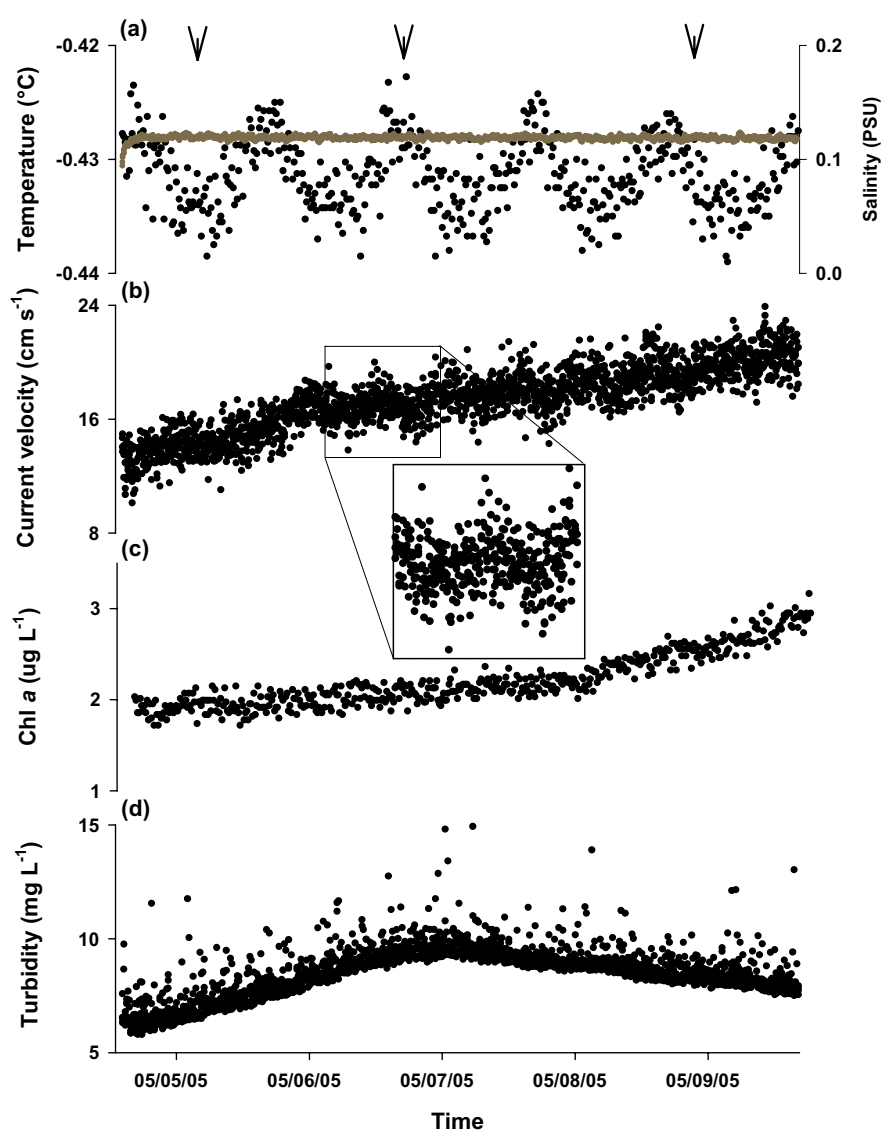

FIG. 3. Mooring data from 2-D-ACM current meter and integrated Turner designs fluorometer $\left(\right.$ SCUFA $^{\circledR}$, model 10 series). (a) Temperature (filled circles) and salinity (grey circles); (b) Current velocity, with inset illustrating fluctuations occurring over semi-diurnal tidal periods; (c) Chlorophyll $a$ concentration; (d) Turbidity concentration (calibrated against field-truthed suspended particulate matter (SPM) concentrations). Arrows indicate times of water sampling.

small, but significant ( $p<0.05$, one-way ANOVA): the spring ratios were slightly higher, probably reflecting the lower $\mathrm{OM}$ and TOC contents during the spring. For the remaining physical sediment characteristics (e.g., grainsize, density, and porosity), there were no significant differences between seasons or across years. Sediments were composed primarily of sandy silts with similar median grain-size compositions $\left(\mathrm{D}_{50}=25-50 \mu \mathrm{m}\right)$ (Table 1$)$. Composition of sediment texture and grain-size distribution are illustrated by a GRADISTAT probability plot (Fig. 5). The deployment of duplicate sediment traps under landfast ice conditions produced sedimentation rates of $51 \mathrm{~g} \mathrm{~m}^{-2} \mathrm{~d}^{-1}$, whereas the summer values were much higher, at over $5000 \mathrm{~g} \mathrm{~m}^{-2} \mathrm{~d}^{-1}$ (Table 1).

Comparison of organic quality in seston and trapped material demonstrates substantial seasonal differences (Table 2). There is a relatively high phytoplankton abundance in May (when discharge and water turbidity are lower) than in summer, which is reflected in higher pigment and organic matter contents in seston than in suspended sediments in the sediment traps. Total organic content of trapped particles was similar between seasons, but organic content of seston in spring samples was twice 
TABLE 1 . Summary of water column environmental data $(1 \mathrm{~m})$ and physical characteristics of surface sediments $(0-1 \mathrm{~cm})$ in $\mathrm{Kugmallit}$ Bay during spring and summer. ${ }^{1}$ Values represent means $( \pm \mathrm{SE}, \mathrm{n}=3-1955)$.

\begin{tabular}{|c|c|c|c|c|c|c|c|c|c|c|c|c|c|}
\hline \multirow[b]{2}{*}{ Season } & \multicolumn{7}{|c|}{ Water column $(1 \mathrm{~m})$} & \multicolumn{6}{|c|}{ Sediments $(0-1 \mathrm{~cm})$} \\
\hline & $\begin{array}{l}\text { Temp. } \\
\left({ }^{\circ} \mathrm{C}\right)\end{array}$ & $\begin{array}{l}\text { Salinity } \\
\text { (PSU) }\end{array}$ & $\begin{array}{l}\text { Current } \\
\text { velocity } \\
\left(\mathrm{m} \mathrm{s}^{-1}\right)\end{array}$ & $\begin{array}{l}\text { Chl } a \\
\left(\mu \mathrm{g} \mathrm{L}{ }^{-1}\right)\end{array}$ & $\begin{array}{l}\text { SPM } \\
\left(\mathrm{mg} \mathrm{L}^{-1}\right)\end{array}$ & $\begin{array}{l}\text { OM of } \\
\text { SPM } \\
\text { filters (\%) }\end{array}$ & $\begin{array}{l}\text { Sedimentation } \\
\text { rate }\left(\mathrm{g} \mathrm{m}^{-2} \mathrm{~d}^{-1}\right)\end{array}$ & $\begin{array}{l}\text { Mean } \\
\text { density } \\
\left(\mathrm{g} \mathrm{mL}^{-1}\right)\end{array}$ & $\begin{array}{l}\text { Mean } \\
\text { porosity }\end{array}$ & $\begin{array}{r}\text { OM } \\
\mathrm{y}(\%)\end{array}$ & $\begin{array}{l}\text { TOC } \\
(\%)\end{array}$ & $\begin{array}{l}\mathrm{C} / \mathrm{N} \\
\text { ratio }\end{array}$ & $\begin{array}{l}\text { Grain-size } \\
\text { characteristics } \\
(\mu \mathrm{m})\end{array}$ \\
\hline $\begin{array}{l}\text { Spring } \\
\text { (May) }\end{array}$ & $\begin{array}{c}-0.43 \\
(0.0001)\end{array}$ & $\begin{array}{c}0.12 \\
(0.0001)\end{array}$ & 17.3 & $\begin{array}{l}2.21 \\
(0.01)\end{array}$ & $\begin{array}{c}8.51 \\
(0.02)\end{array}$ & $\begin{array}{l}1.17 \\
(0.13)\end{array}$ & 51 & $\begin{array}{c}1.99 \\
(0.33)\end{array}$ & $\begin{array}{l}0.48 \\
(0.01)\end{array}$ & $\begin{array}{l}2.87 \\
(0.15)\end{array}$ & $\begin{array}{l}1.15 \\
(0.08)\end{array}$ & $\begin{array}{l}22.12 \\
(0.49)\end{array}$ & $\begin{array}{l}\text { Sandy silts or silts } \\
\left(D_{50}=25-50 \mu \mathrm{m}\right)\end{array}$ \\
\hline $\begin{array}{l}\text { Summer } \\
\text { (July) }\end{array}$ & $\begin{array}{l}12.36 \\
(0.55)\end{array}$ & $\begin{array}{c}0.10 \\
(0.01)\end{array}$ & 21.1 & $\begin{array}{l}202.23 \\
(13.52)\end{array}$ & $\begin{array}{l}47.98 \\
(2.97)\end{array}$ & $\begin{array}{l}10.86 \\
(0.77)\end{array}$ & 5386 & $\begin{array}{c}2.01 \\
(0.21)\end{array}$ & $\begin{array}{c}0.49 \\
(0.01)\end{array}$ & $\begin{array}{l}7.88 \\
(0.05)\end{array}$ & $\begin{array}{l}3.95 \\
(0.13)\end{array}$ & $\begin{array}{l}19.94 \\
(0.39)\end{array}$ & $\begin{array}{l}\text { Sandy silts or silts } \\
\left(D_{50}=25-50 \mu \mathrm{m}\right)\end{array}$ \\
\hline
\end{tabular}

${ }^{1} \mathrm{SPM}=$ suspended particulate matter; OM of SPM = organic matter of suspended particulate matter residues determined by loss on ignition; $\mathrm{OM}=$ organic matter of surface sediments; $\mathrm{TOC}=$ total organic carbon of surface sediments derived from $\mathrm{CHN}$ analysis.
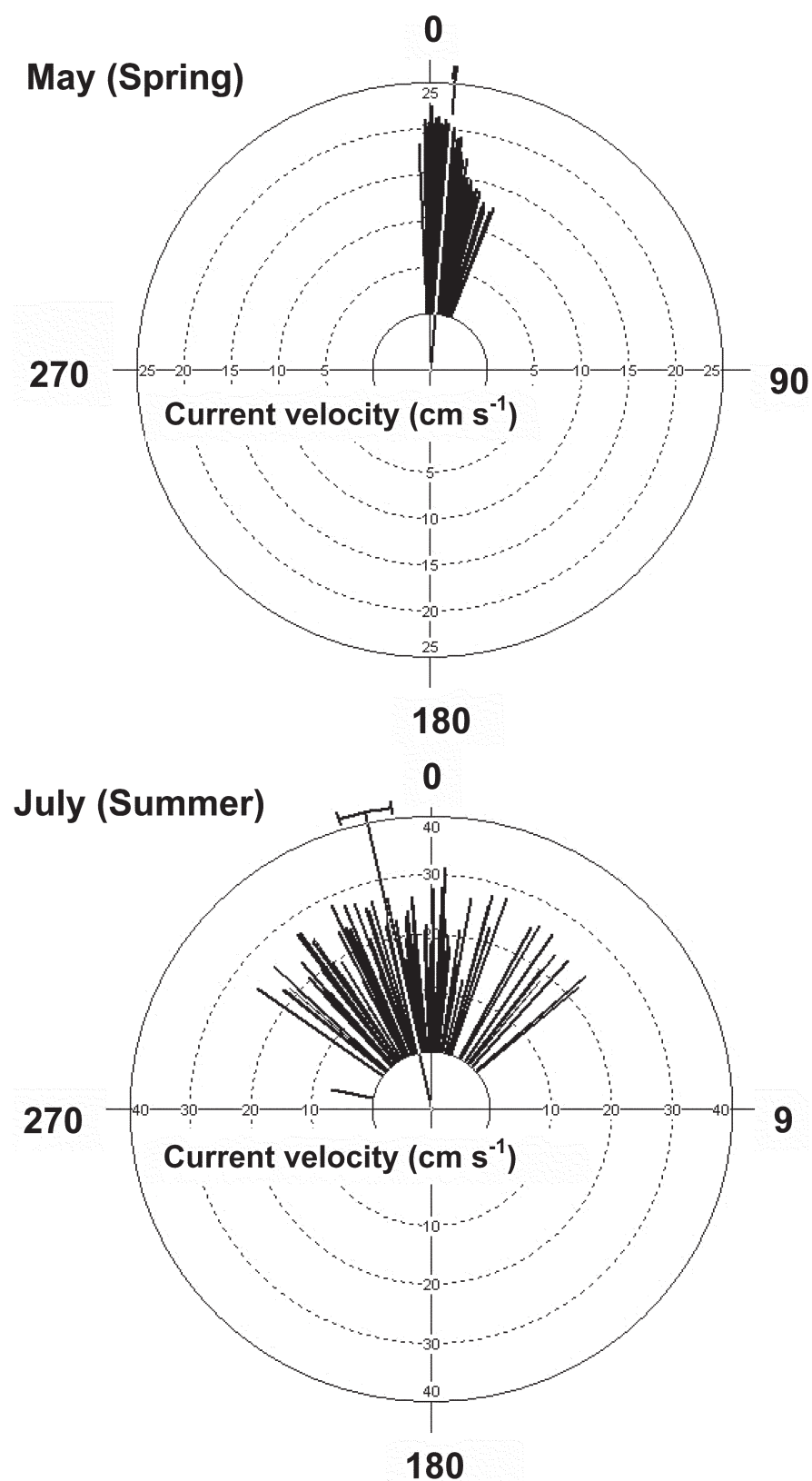

FIG. 4. Current velocities $\left(\mathrm{cm} \mathrm{s}^{-1}\right)$ and flow direction from current-meter deployments at the sampling site in Kugmallit Bay for spring (May) and summer (July).

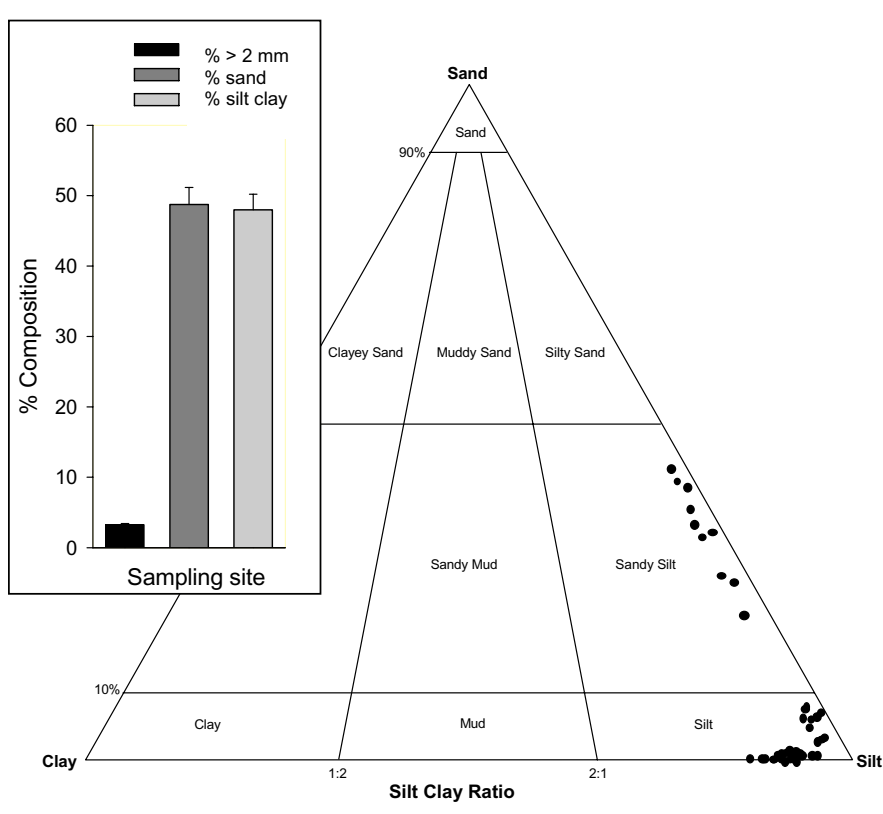

FIG. 5. Results of grain-size analysis and composition of sediment texture from sampling site in Kugmallit Bay. Legend indicates categories as \% silt-clay $(<63 \mu \mathrm{m}) ; \%$ sand $(63-2000 \mu \mathrm{m}) ; \%$ gravel $(>2000 \mu \mathrm{m})$. Plotted values are means $\pm \operatorname{SE}(n=3)$

as high as in summer samples, again reflecting the richer seston under the ice. In July, after the nival freshet has terminated, the high turbidity in the Mackenzie plume suppresses primary production at the study site, and this situation is reflected in the decline in pigment and organic matter contents in the seston. Our previous results suggested that pigment content showed a greater differential between traps and seston than did organic content, since phytoplankton were less likely than detritus to settle into the sediment traps. This effect is intensified in spring, when the seston is 47 times as rich in pigments as in TOC, reflecting the relatively greater contribution of phytoplankton during that season.

The Mackenzie River farther south had already begun its spring ice breakup by 12 May 2005 between Arctic Red River ( $67^{\circ} 25^{\prime} 46^{\prime \prime} \mathrm{N}, 133^{\circ} 42^{\prime} 28^{\prime \prime} \mathrm{W}$ ) and Fort Good Hope $\left(66^{\circ} 15^{\prime} 45^{\prime \prime} \mathrm{N}, 128^{\circ} 28^{\prime} 56^{\prime \prime} \mathrm{W}\right)$, approximately $500 \mathrm{~km}$ 
TABLE 2. Comparison of organic quality in seston and sediment traps.

\begin{tabular}{lcclcc}
\hline \hline & \multicolumn{2}{c}{ Sediment Trap Contents } & & \multicolumn{2}{c}{ Seston } \\
\cline { 2 - 3 } \cline { 5 - 6 } \cline { 5 - 6 } & $\begin{array}{c}\text { Pigments } \\
\left(\mu \mathrm{g} \mathrm{g}^{-1}\right)\end{array}$ & $\begin{array}{c}\text { POM } \\
(\%)\end{array}$ & & $\begin{array}{c}\text { Pigments } \\
\left(\mu \mathrm{g} \mathrm{g}^{-1}\right)\end{array}$ & $\begin{array}{c}\text { POM } \\
(\%)\end{array}$ \\
\hline July (Summer) & 2.19 & 5.79 & & 57.73 & 10.86 \\
May (Spring) & 11.58 & 5.82 & & 542.43 & 22.92 \\
\hline \hline
\end{tabular}

south of our study area (T.R. Walker, pers. obser.). Our study covers only early May 2005, but Table 3 shows the interannual variation in timing of peak discharge and water levels along the Mackenzie River between 1966 and 1984, and the date of ice clearance at Inuvik. These data show that the nival freshet and ice clearance upstream of the study site may occur as early as mid-May (Hill et al., 2001). The peak discharge at Norman Wells, for example, has been observed as early as 17 May, suggesting that ice breakup and spring melt would have occurred before this date.

\section{Determining Material Fluxes}

The mean total discharge $(Q t)$ during the sampling period in May was $3.81 \times 10^{8} \mathrm{~m}^{3} \mathrm{~d}^{-1}$, with a TOC flux through this cross-section $(F)$ of $1.59 \times 10^{6} \mathrm{~g} \mathrm{~d}^{-1}$ (assuming, on the basis of sediment CHN elemental analysis, that TOC represents $0.42 \%$ of the organic matter content of SPM). As the eastern channel of the Mackenzie River represents only $11 \%$ of the total river discharge (Carson et al., 1999), the TOC flux entering the Beaufort Shelf from the Mackenzie River would be much larger.

\section{DISCUSSION}

While these data are limited in scope and represent small spatial and temporal scales, we report early signs of a spring melt through the subtle changes in biological and oceanographic water-column variables. These signals, along with comparison of variations in sediment characteristics between seasons and across years, may help our understanding of the timing of the spring freshet and the mechanism by which sediment is transported early in the season. The onset of the freshet normally occurs in May. In 1973 - 1990, the mean Mackenzie River flow increased from $5000 \mathrm{~m}^{-3} \mathrm{~s}$ to $25000 \mathrm{~m}^{-3} \mathrm{~s}$ during this month (Carmack and Macdonald, 2002).

Kugmallit Bay on the eastern channel of the Mackenzie Delta accounts for approximately $11 \%$ of the total river discharge of the Mackenzie River (Carson et al., 1999). While the inner shelf acts as a repository of organic carbon, it is not known what proportion of the available carbon escapes shallow water in particulate form and becomes available for export to deep water. During May 2005, the mean chlorophyll $a$ concentration in Kugmallit
TABLE 3. Timing of peak discharge and water levels between 1966 and 1984 and date of ice clearance at Inuvik. Data from Hill et al. (2001).

\begin{tabular}{|c|c|c|c|c|c|c|c|}
\hline \multirow{3}{*}{$\begin{array}{l}\text { Year } \\
1966\end{array}$} & \multicolumn{2}{|c|}{$\begin{array}{l}\text { Mackenzie } \\
\text { at Norman Wells } \\
\text { (Max. discharge) }\end{array}$} & \multicolumn{2}{|c|}{$\begin{array}{l}\text { Mackenzie above } \\
\text { Arctic Red River } \\
\text { (Max. discharge) }\end{array}$} & \multicolumn{3}{|c|}{$\begin{array}{c}\text { East Channel } \\
\text { at Inuvik } \\
\text { (Max. water level) }\end{array}$} \\
\hline & Date & $\left(\mathrm{m}^{3} \mathrm{~s}^{-1}\right)$ & Date & $\left(\mathrm{m}^{3} \mathrm{~s}^{-1}\right)$ & Date & $\begin{array}{l}\text { End of ic } \\
\text { condition }\end{array}$ & (m) \\
\hline & June 20 & 20800 & - & - & June 5 & June 9 & 7.4 \\
\hline 1967 & June 4 & 22500 & - & - & June 6 & June 5 & 8.6 \\
\hline 1968 & June 30 & 25000 & - & - & June 6 & June 8 & 7.8 \\
\hline 1969 & June 17 & 17400 & - & - & June 2 & June 4 & 7.2 \\
\hline 1970 & July 22 & 26600 & - & - & June 3 & June 3 & 7.7 \\
\hline 1971 & June 24 & 21500 & - & - & May 31 & June 2 & 8.8 \\
\hline 1972 & July 25 & 25500 & - & - & June 7 & June 12 & 10.4 \\
\hline 1973 & June 23 & 24800 & June 26 & 26600 & May 30 & May 31 & 9.0 \\
\hline 1974 & May 26 & 27500 & May 30 & 30300 & June 6 & June 9 & 8.3 \\
\hline 1975 & May 24 & 30300 & May 28 & 34000 & June 3 & June 4 & 8.6 \\
\hline 1976 & July 6 & 22000 & May 24 & 32000 & May 29 & June 8 & 8.3 \\
\hline 1977 & May 17 & 28300 & June 12 & 29200 & May 31 & June 10 & 8.0 \\
\hline 1978 & May 20 & 24100 & June 5 & 28300 & June 9 & June 15 & 8.0 \\
\hline 1979 & July 9 & 24900 & May 31 & 28600 & May 31 & June 10 & 8.5 \\
\hline 1980 & - & - & May 29 & 26400 & June 4 & June 7 & 7.3 \\
\hline 1981 & - & - & May 24 & 28300 & May 24 & May 30 & 7.6 \\
\hline 1982 & May 25 & 26900 & June 4 & 28800 & June 3 & June 10 & 9.4 \\
\hline 1983 & May 29 & 25000 & June 2 & 29000 & June 6 & June 15 & 8.9 \\
\hline 1984 & June 15 & 19800 & June 19 & 22100 & May 28 & June 3 & - \\
\hline Mean & June 14 & 23940 & June 4 & 28630 & June 2 & June 7 & 8.3 \\
\hline
\end{tabular}

Bay was only $2.2 \mu \mathrm{g} \mathrm{L}^{-1}$ and probably reflected typical early spring concentrations due to the $24 \mathrm{~h}$ exposure to the sun available at this time of year at this latitude. The small chlorophyll $a$ increase could have resulted from this abundant insolation, but it is possible that the thickness of the ice prevented sufficient light penetration. Therefore, some other mechanisms may have contributed to the increase in chlorophyll $a$, such as removal of ice algal communities as increasing river flow scoured the underside of the ice, or the onset of a spring bloom occurring farther south in the drainage basin. By 12 May 2005, river-ice breakup had already begun between Arctic Red River and Fort Good Hope, ca. $500 \mathrm{~km}$ south of our study area (T.R. Walker, pers. observ.). Carmack et al. (2004) calculated primary production across the shelf during spring (ice cover) to be about $10 \mathrm{mg} \mathrm{C} \mathrm{m}^{-2} \mathrm{~d}^{-1}$, rising to about $200 \mathrm{mg} \mathrm{C} \mathrm{m}^{-2} \mathrm{~d}^{-1}$ by late July, with a total production for 1987 estimated at 12 to $16 \mathrm{~g} \mathrm{C} \mathrm{m}^{-2}$, and concluded that primary production was limited primarily by nutrients rather than by light limitation from ice or sediment turbidity (which controls the timing of peak productivity).

This study covers only early May 2005, but Table 3 illustrates the interannual variation in the timing of peak discharges and ice breakup along the Mackenzie River between 1966 and 1984. Peak discharge at Norman Wells has been observed as early as 17 May, suggesting that ice breakup and spring melt would have occurred before this date (Table 3; Hill et al., 2001). The mean date for ice clearance at Inuvik (farther downriver) over the same period occurs several weeks later, on 7 June. The increase in current velocity beneath the ice in Kugmallit Bay may 
have been influenced by the spring melt and rising discharges farther south, or may be due to tidal forcing or wind stress. Significant current fluctuations also occur over semi-diurnal tidal periods (Hill et al., 2001), which were also observed in our current velocity measurements beneath the ice.

The highest salinity value recorded during the spring or summer study was 0.12 PSU, suggesting that the large input of freshwater from the Mackenzie River at this inshore site is not influenced by denser Arctic water. Farther offshore in Kugmallit Bay, however, it is widely reported that pronounced stratification, with horizontal gradients in salinity and temperature, occurs during the open water season (e.g., Yunker et al., 1995, 2005; Macdonald et al., 1998; Hill et al., 2001). Since the riverine input to the Mackenzie Shelf is seasonal, much of the substantial SPM load was discharged after our sampling period, during the spring breakup of landfast ice. Much of this SPM load is probably maintained in suspension during the ice-free period along with re-suspended material (Macdonald and Thomas, 1991). During summer 2004 we observed an "unsettleable" fraction in our own sedimentation traps, which remained in suspension despite standing overnight in the dark (Walker et al., in press). These particles may have been colloidal, kept in suspension by van der Waals forces, or just low-settling. Sediment fluxes measured during spring by the deployment of sediment traps in Kugmallit Bay produced sedimentation rates of $51 \mathrm{~g} \mathrm{~m}^{-2} \mathrm{~d}^{-1}$. However, there appeared to be no "unsettleable" fraction during the spring, and so there was no need to eliminate this component from the trap data.

Macdonald and Thomas (1991) found sedimentation rates of 25 to $42 \mathrm{~g} \mathrm{~m}^{-2} \mathrm{~d}^{-1}$ at $1.8 \mathrm{~m}$ above the seabed under ice in Kugmallit Bay, in water depths less than $10 \mathrm{~m}$. Deployments of sediment traps at the same site under open-water conditions recorded rates between 6300 to $8100 \mathrm{~g} \mathrm{~m}^{-2} \mathrm{~d}^{-1}$. Sedimentation rates reported here for spring 2005 were comparable, as were those for the same site under open-water conditions $\left(>5000 \mathrm{~g} \mathrm{~m}^{-2} \mathrm{~d}^{-1}\right)$ (Walker et al., in press).

Sediments in Kugmallit Bay were dominated by sandy silt or silt (see Fig. 5), corresponding well to the Mackenzie plume, with its fine components (and associated carbon), which extends well beyond this site (Hill et al., 1991; Macdonald et al., 1998). The TOC and OM values in sediments reported for this site are influenced by the fine sediment fractions of the Mackenzie River, which transport organic-rich suspensions as flocs (Droppo et al., 1998), as well as sediment grain-size composition (Grant et al., 2002). Organic matter and TOC content of surface sediments were relatively high considering the only possible sources of fresh organic input were river-based primary production or scoured ice algae. However, these values for OM and TOC content were less than half of those from the previous summer (Table 1; Walker et al., in press). The reduction in surface OM and TOC content during the spring may have been due to remineralization within surface sediments (Nedwell et al., 1993; Nedwell and Walker, 1995; Renaud et al., 2007) or remineralization within the water column by pelagic organisms, which left little organic detritus to be delivered to the seabed (Tremblay et al., 2006). Redfield (1934) indicates that the molar element ratio of $\mathrm{C} / \mathrm{N}$ in most phytoplankton is 106:16 ( 7), and the diagenesis of organic carbon would normally be expected to occur more rapidly for this "redfield" material than for terrigenous material $(\mathrm{C} / \mathrm{N}$ ratios $>10$ ), which means that remineralization would produce higher $\mathrm{C} / \mathrm{N}$ ratios. This expectation is corroborated by evidence of $\mathrm{C} / \mathrm{N}$ ratios, which indicate that there is less carbon but more nitrogen in surface sediments during the spring, although both spring and summer $\mathrm{C} / \mathrm{N}$ ratios remain high. Walker (2005) also noted that $\mathrm{OM}$ and TOC contents in shallow Antarctic surface sediments were reduced during spring after prolonged ice cover. The high values for sediment $\mathrm{C} / \mathrm{N}$ ratios in Kugmallit Bay were similar to those reported by Guo et al. (2004), who measured increasing sediment $\mathrm{C} / \mathrm{N}$ ratios close to terrestrial inputs of the $\mathrm{Ob}$, Yenisey, Khatanga, Lena, and Indigirka estuaries along the Siberian Arctic coastline. The riverine sediment (collected from SPM and sediment traps) is composed of two sources: terrigenous material dominated by inorganic components (with high $\mathrm{C} / \mathrm{N}$ ratios), and organic algal matter produced in the aquatic system (with lower $\mathrm{C} / \mathrm{N}$ ratios and higher chlorophyll $a$ concentrations, both of which vary independently to affect the final composition). During our spring sampling period, however, the $\mathrm{C} / \mathrm{N}$ ratios remained high and the chlorophyll $a$ concentrations were low, suggesting a large terrigenous source rather than an algal one.

At water depths under $10 \mathrm{~m}$ in Kugmallit Bay, Hill et al. (2001) reported mean TOC values of 5\% during summer. They concluded that the organic carbon was composed principally of allochthonous (terrigenous) components derived from the Mackenzie River (Yunker et al., 1995, 2005). The TOC results reported here (1\% for spring and $4 \%$ for summer) compare well with these values. Horizontal and vertical transport of organic carbon and SPM in the surface layers of the Mackenzie Shelf and Beaufort Sea shows significant seasonal variation, with winter concentrations as low as 3 to $12 \mathrm{mg} \mathrm{L}^{-1}$ and peak summer concentrations reaching up to $4000 \mathrm{mg} \mathrm{L}^{-1}$ (Hill et al., 1991; Macdonald et al., 1998). Indeed, our own results of spring SPM concentrations of $8.5 \mathrm{mg} \mathrm{L}^{-1}$ fall within these values and are still within typical "winter plume" levels (Carmack et al., 2004). Our summer SPM concentrations of $48 \mathrm{mg} \mathrm{L}^{-1}$ (collected during July) were probably below peak concentrations (Macdonald et al., 1998), although these measurements do demonstrate significant seasonal variation. This variation was also corroborated by the comparison of organic quality in seston and trapped material, which demonstrated substantial seasonal differences (Table 2).

The small increase in turbidity noted while the traps were deployed could be partly due to re-suspension of less 
consolidated surface sediments. This re-suspension could have been caused by increasing shear stress as the water was forced through narrow channels between the ice and the sediment bed (Macdonald et al., 1999), or by increased Mackenzie River flow from farther upstream, where breakup had already begun. The majority of sediments in the Mackenzie plume during winter or summer are transported eastward from the delta and into the Arctic Basin (Hill et al., 1991). Another route for sediment transport on the Mackenzie Shelf is via incorporation in sea ice, which is carried out into the Arctic Ocean by winds and currents (Eicken et al., 2005).

This paper reports subtle changes in biological and oceanographic variables beneath landfast ice in Kugmallit Bay that suggest the onset of a spring melt occurring hundreds of kilometres farther south in the Mackenzie valley. The timing of these events is important if we are to understand how sediment and carbon are transported to the Arctic Ocean and their subsequent impact on primary production. Therefore, the large amount of allochthonous and autochthonous material supplied by the Mackenzie River under seasonal ice cover has important consequences for carbon and sediment sequestration or export (Macdonald et al., 1998; Goñi et al., 2005). Climate change and warming scenarios are predicted to be more pronounced in the Arctic, where earlier snowmelt events are likely to occur as a result (IPCC, 2001; Comiso, 2003). The result will be longer ice-free periods, particularly in the seasonal ice zone over the shelves (Macdonald et al., 1995). Increased open water will increase wind mixing, sediment re-suspension, and upwelling, and thus increase both nutrient availability to phytoplankton and primary production, which are critical to the total carbon budget and trophic dynamics on the Canadian Shelf of the Beaufort Sea (Macdonald et al., 1998, 2003; Carmack et al., 2004; O'Brien et al., 2006). Open water will also increase the availability of underwater light to phytoplankton, but the increased turbidity of the water column will suppress primary production. A decrease in ice cover will also decrease ice algae production, with consequences to pelagic and benthic food webs (Carmack and Macdonald, 2002).

The results from deployment of moored sensors and sediment traps under landfast ice reported here help us further understand the timing of ice breakup on the Mackenzie Delta. These data, in combination with other data sources (such as river station discharge data) and the use of remote sensing techniques, will also be of use for predicting earlier ice breakup due to warming of the Arctic in the future.

\section{ACKNOWLEDGEMENTS}

Special thanks to James and Maureen Pokiak and Robin Felix of Ookpik Tours and Adventures in Tuktoyaktuk. We thank Paul MacPherson, Jeff Barrell, Marie-Claude Archambault, and Paul Hill at Dalhousie University. This sub-project formed part of the
Canadian Arctic Shelf Exchange Study (CASES) project, which was funded by the Natural Sciences and Engineering Research Council of Canada (NSERC) and covered by Scientific Research Licence number 13796R, issued by Aurora Research Institute (ARI). The Inuvik and Tuktoyaktuk Hunters and Trappers Committees and Inuvik Environmental Impact Screening Committee also gave their approval for the work in Kugmallit Bay. We wish to thank Andrew Applejohn and Rita I. Kors-Olthof of ARI for expediting this licence. We would also like to thank Drs. Alec Aitken and Gwyn Lintern for constructive comments to improve this paper.

\section{REFERENCES}

AMERICAN PUBLIC HEALTH ASSOCIATION. 1998. Standard methods for the examination of water and wastewater, 20th ed. Washington, D.C.

ARAR, E.J., and COLLINS, G.B. 1997. In vitro determination of chlorophyll- $a$ and pheophytin- $a$ in marine and freshwater phytoplankton by fluorescence. Revision 1.2. Cincinnati, Ohio: National Exposure Research Laboratory, U.S. Environmental Protection Agency.

BARBER, D.G., and HANESIAK, J.M. 2004. Meteorological forcing of sea ice concentrations in the southern Beaufort Sea over the period 1979 to 2000. Journal of Geophysical Research 109:C06014, doi:10.1029/2003JC002027.

BLOESCH, J. 1994. A review of methods used to measure sediment resuspension. Hydrobiologia 284(1):13-18, doi:10.1007/ BF00005728.

BLOTT, S.J., and PYE, K. 2001. GRADISTAT: A grain-size distribution and statistics package for the analysis of unconsolidated sediments. Earth Surface Processes and Landforms 26:1237-1248.

BURENKOV, V.I., KUPTZOV, V.M., SIVKOV, V.V., and SHEVCHENKO, V.P. 1997. Spatial distribution and size composition of suspended matter in the Laptev Sea in AugustSeptember 1991. Oceanology 37:831-837.

CARMACK, E.C., and MACDONALD, R.W. 2002. Oceanography of the Canadian Shelf of the Beaufort Sea: A setting for marine life. Arctic 55(Suppl. 1):29-45.

CARMACK, E.C., MACDONALD, R.W., and JASPER, S.E. 2004. Phytoplankton productivity on the Canadian Shelf of the Beaufort Sea. Marine Ecology Progress Series 277:37-50, doi:10.3354/meps 277037.

CARSON, M.A., CONLY, F.M., and JASPER, J.N. 1999. Riverine sediment balance of the Mackenzie Delta, Northwest Territories, Canada. Hydrological Processes 13:2499-2518.

COMISO, J.C. 2003. Warming trends in the Arctic from clear sky satellite observations. Journal of Climate 16:3498-3510.

CONLAN, K., and KVITEK, R. 2005. Recolonization of softsediment ice scours on an exposed Arctic coast. Marine Ecology Progress Series 286:21-42.

DEAN, K.G., STRINGER, W.J., AHLNÄS, K., SEARCY, C., and WEINGARTNER, T. 1994. The influence of river discharge on the thawing of sea ice, Mackenzie River Delta: Albedo and temperature analyses. Polar Research 13:83-94. 
DROPPO, I.G., JEFFRIES, D., JASKOT, C., and BACKUS, S. 1998. The prevalence of freshwater flocculation in cold regions: A case study from the Mackenzie River Delta, Northwest Territories, Canada. Arctic 51(2):155-164.

EICKEN, H., GRADINGER, R., GAYLORD, A., MAHONEY, A., RIGOR, I., and MELLING, H. 2005. Sediment transport by sea ice in the Chukchi and Beaufort seas: Increasing importance due to changing ice conditions? Deep-Sea Research Part II 52:3281-3302.

FOREST, A., SAMPEI, M., HATTORI, H., MAKABE, R., SASAKI, H., FUKUCHI, M., WASSMANN, P., and FORTIER, L. 2006. Particulate organic carbon fluxes on the slope of the Mackenzie Shelf (Beaufort Sea): Physical and biological forcing of shelf-basin exchanges. Journal of Marine Systems 68(1-2): 39-54, doi:10.1016/j.jmarsys.2006.10.008.

GOÑI, M.A., YUNKER, M.B., MACDONALD, R.A., and EGLINTON, T.I. 2005. The supply and preservation of ancient and modern components of organic carbon in the Canadian Beaufort Shelf of the Arctic Ocean. Marine Chemistry 93: $53-73$.

GRANT, J., HARGRAVE, B.T., and MACPHERSON, P. 2002. Sediment properties and benthic-pelagic coupling in the North Water. Deep-Sea Research Part II 49:5259-5275.

GUO, L., SEMILETOV, I., GUSTAFSSON, Ö., INGRI, J., ANDERSSON, P., DUDAREV, O., and WHITE, D. 2004. Characterization of Siberian Arctic coastal sediments: Implications for terrestrial organic carbon export. Global Biogeochemical Cycles 18:GB1036, doi:10.1029/2003GB 002087.

HARPER, J.R., HENRY, R.F., and STEWART, G.G. 1988. Maximum storm surge elevations in the Tuktoyaktuk region of the Canadian Beaufort Sea. Arctic 41(1):48-52.

HILL, P.R., and NADEAU, O.C. 1989. Storm-dominated sedimentation on the inner shelf of the Canadian Beaufort Sea. Journal of Sedimentary Petrology 59:455-468.

HILL, P.R., BLASCOE, S.M., HARPER, J.R., and FISSEL, D.B. 1991. Sedimentation in the Canadian Beaufort Shelf. Continental Shelf Research 11:821-842.

HILL, P.R., LEWIS, C.P., DESMARAIS, S., KAUPPAYMUTHOO, V., and RAIS, H. 2001. The Mackenzie Delta: Sedimentary processes and facies of a high-latitude, fine-grained delta. Sedimentology 48:1047-1078.

HUME, T.M., and BELL, R.G. 1993. Methods for determining tidal flows and material fluxes in estuarine cross-sections. Water Quality Centre Publication No. 22. Hamilton, New Zealand: National Institute of Water and Atmospheric Research. 43 p.

IPCC (INTERGOVERNMENTAL PANEL ON CLIMATE CHANGE). 2001. Climate change 2001: The scientific basis. Contribution of Working Group I to the Third Assessment Report of the Intergovernmental Panel on Climate Change, edited by J.T. Houghton, Y. Ding, D.J. Griggs, M. Noguer, P.J. van der Linden, X. Dai, K. Maskell, and C.A. Johnson. Cambridge: Cambridge University Press. $881 \mathrm{p}$.

KUPTSOV, V.M., LISITSIN, A.P., SHEVCHENKO, V.P., and BURENKOV, V.I. 1999. Suspended matter fluxes in the bottom sediments of the Laptev Sea. Oceanology 39:597-604.
LINTERN, D.G., HILL, P.R., SOLOMON, S., WALKER, T.R., and GRANT, J. 2005. Erodibility, sediment strength and storm resuspension in Kugmallit Bay, Beaufort Sea. Proceedings of the 12th Canadian Coastal Conference, 6-9 November 2005, Dartmouth, Nova Scotia. 13 p.

MACDONALD, R.W. 2000. Arctic estuaries and ice: A positivenegative estuarine couple. In: Lewis, E.L., ed. The freshwater budget of the Arctic Ocean. Netherlands: Kluwer Academic Publishers. 383-407.

MACDONALD, R.W., and THOMAS, D.J. 1991. Chemical interactions and sediments of the western Arctic Shelf. Continental Shelf Research 11:843-863.

MACDONALD, R.W., PATON, D.W., CARMACK, E.C., and OMSTEDT, A. 1995. The freshwater budget and under-ice spreading of Mackenzie River water in the Canadian Beaufort Sea based on salinity and ${ }^{18} \mathrm{O} /{ }^{16} \mathrm{O}$ measurements in water and ice. Journal of Geophysical Research 100 C1:895-919.

MACDONALD, R.W., SOLOMON, S.M., CRANSTON, R.E., WELCH, H.E., YUNKER, M.B., and GOBEIL, C. 1998. A sediment and organic carbon budget for the Canadian Beaufort Shelf. Marine Geology 144:255-273.

MACDONALD, R.W., CARMACK, E.C., McLAUGHLIN, F.A., FALKNER, K.K., and SWIFT, J.H. 1999. Connections among ice, runoff and atmospheric forcing in the Beaufort Gyre. Geophysical Research Letters 26:2223-2226.

MACDONALD, R.W., NAIDU, A.S., YUNKER, M.B., and GOBEIL, C. 2003. The Beaufort Sea: Distribution, sources, variability and burial of carbon. In: Stein, R., and Macdonald, R.W., eds. The Arctic Ocean organic carbon cycle present and past. Berlin and New York: Springer Publishing Company. $177-193$.

NEDWELL, D.B., and WALKER, T.R. 1995. Sediment-water fluxes of nutrients in an Antarctic coastal sediment: Influence of bioturbation. Polar Biology 15:57-64.

NEDWELL, D.B., WALKER, T.R., ELLIS-EVANS, J.C., and CLARKE, A. 1993. Measurements of seasonal rates and annual budgets of organic carbon fluxes in an Antarctic coastal environment at Signy Island, South Orkney Islands, suggest a broad balance between production and decomposition. Applied and Environmental Microbiology 59:3989-3995.

O'BRIEN, M.C., MACDONALD, R.W., MELLING, H., and ISEKI, K. 2006. Particle fluxes and geochemistry on the Canadian Beaufort Shelf: Implications for sediment transport and deposition. Continental Shelf Research 26:41-81.

PAVELSKY, T.M., and SMITH, L.C. 2004. Spatial and temporal patterns in Arctic river ice breakup observed with MODIS and AVHRR time series. Remote Sensing of Environment 93: $328-338$

REDFIELD, A.C. 1934. On the proportions of organic derivations in sea water and their relation to the composition of plankton. In: Daniel, R.J., ed. James Johnson Memorial Volume. Liverpool: University Press of Liverpool. 177-192.

RENAUD, P.E., RIEDEL, A., MICHEL, C., MORATA, N., GOSSELIN, M., JUUL-PEDERSEN, T., and CHIUCHIOLO, A. 2007. Seasonal variation in benthic community oxygen demand: A response to an ice algal bloom in the Beaufort Sea, 
Canadian Arctic? Journal of Marine Systems 67(1-2):1-12, doi:10.1016/j.jmarsys.2006.07.006.

TREMBLAY, J.-E., HATTORI, H., MICHEL, C., RINGUETTE, M., MEI, Z.-P., LOVEJOY, C., FORTIER, L., HOBSON, K.A., AMIEL, D., and COCHRAN, K. 2006. Trophic structure and pathways of biogenic carbon flow in the eastern North Water Polynya. Progress in Oceanography 71:402-425.

USHER, P.J. 2002. Inuvialuit use of the Beaufort Sea and its resources, 1960-2000. Arctic 55(Suppl. 1):18-28.

WALKER, T.R. 2005. Vertical organic inputs and bio-availability of carbon in an Antarctic coastal sediment. Polish Polar Research 26(2):91-106.

WALKER, T.R., GRANT, J., HILL, P.S., CRANFORD, P., LINTERN, D.G., and SCOFIELD, B. 2005. Measuring particle dynamics in Arctic and mussel aquaculture environments. Proceedings of the 12th Canadian Coastal Conference, 6-9 November 2005, Dartmouth, Nova Scotia. 11 p.
WALKER, T.R., GRANT, J., CRANFORD, P., LINTERN, D.G., HILL, P.., JARVIS, P., BARRELL, J., and NOZAIS, C. In press. Suspended sediment and erosion dynamics in Kugmallit Bay and Beaufort Sea during ice-free conditions. Journal of Marine Systems (2008), doi:10.1016/j.jmarsys.2008.01.006.

WEGNER, C., HÖLEMANN, J.A., DMITRENKO, I., KIRILLOV, S., TUSCHLING, K., ABRAMOVA, E., and KASSENS, H. 2003. Suspended particulate matter on the Laptev Sea Shelf (Siberian Arctic) during ice-free conditions. Estuarine and Coastal Shelf Science 57:55-64.

YUNKER, M.B., MACDONALD, R.W., VELTKAMP, D.J., and CRETNEY, W.J. 1995. Terrestrial and marine biomarkers in a seasonally ice-covered Arctic estuary: Integration of multivariate and biomarker approaches. Marine Chemistry 49:1-50.

YUNKER, M.B., BELICKA, L.L., HARVEY, H.R., and MACDONALD, R.W. 2005. Tracing the inputs and fate of marine and terrigenous organic matter in Arctic Ocean sediments: A multivariate analysis of lipid biomarkers. Deep-Sea Research Part II 52:3478-3508. 